\section{Oxidative Dealkylation of Tetra-, Tri-, and Dialkyltins and Tetra- and Trialkylleads by Liver Microsomes}

\author{
JOHN E. CASIDA, ELLA C. KIMMEL, \\ BERYL HOLM and GUNNAR WIDMARK
}

\author{
Institute of Analytical Chemistry, University \\ of Stockholm, Stockholm, Sweden, and \\ Division of Entomology, University of \\ California, Berkeley, California, U.S.A.
}

$\mathrm{O}^{\mathrm{r}}$ rganolead and -tin compounds are used extensively as antiknock gasoline additives $\left(\mathrm{Me}_{4} \mathrm{~Pb}\right.$ and $\left.\mathrm{Et}_{4} \mathrm{~Pb}\right)$, stabilizers for chlorinated polymers $\left(\mathrm{Bu}_{2} \mathrm{Sn}^{2+}\right)$, catalysts for a variety of chemical reactions, and biocidal agents $\left(\mathrm{Bu}_{2} \mathrm{Sn}^{2+}, \mathrm{Bu}_{3} \mathrm{Sn}^{+}, \mathrm{Cy}_{3} \mathrm{Sn}^{+}\right.$ and $\left.\mathrm{Ph}_{3} \mathrm{Sn}^{+}\right)$.* The mechanisms and pathways for their biodegradation are not adequately understood despite their presence as environmental contaminants. Tet. raethyllead and -tin are metabolized to their triethyl derivatives in living mammals ${ }^{1-4}$ and by liver microsomes. ${ }^{1,2}$ The triethyl derivatives are relatively stable in vivo ${ }^{1-5}$ but there is slow conversion of triethyllead to inorganic lead, although the intermediates are not known. ${ }^{4}$ Diethyltin is converted in living rats to monoethyltin and an unidentified carbon fragment that is not oxidized to carbon dioxide, but metabolism does not proceed to inorganic tin. ${ }^{6}$ Tricyclohexyltin hydroxide (Plictran ${ }^{\circledR}$ miticide) undergoes sequential dealkylation in living rats to di- and monocyclohexyl derivatives and to inorganic tin.? Triphenyltin is slowly metabolized, possibly to inorganic tin, but the intermediates are not known. ${ }^{8}, 9$ The enzymatic basis for these reactions, other than the conversion of tetraethyl- to triethyllead and -tin,1,2 has not been established and is the subject of this report.

Thin-layer chromatography (TLC) on silica gel chromatoplates (precoated, $0.25 \mathrm{~mm}$ gel

* The abbreviations used are $\mathbf{M e}=$ methyl, Et $=$ ethyl, $\mathrm{Pr}=$ propyl, $\mathrm{Bu}=$ butyl, $\mathrm{Pen}=$ pentyl, Hex = hexyl, Oct=octyl, Cy=cyclohexyl and $\mathrm{Ph}=$ phenyl. The compounds were used as acetates, chlorides, oxides, and hydroxides but the form is not designated here because the results were the same in each case where comparisons were made. thickness, without fluorescence indicator, No. $5721 / 0025$ of E. Merck, Darmstadt, Germany) was used to resolve the organotin and -lead compounds. Various combinations of apolar solvents and acetic acid resolve tetra-, tri- and diorganotins ${ }^{10}$ and the addition of water and acetylacetone to the developer results in resolution of the monoorganotins and tri- and diorganoleads. With these solvent systems, a variation of one carbon in the chain length of a homologous series results in a significant change in $R_{F}$ value. The solvent systems used most frequently for organotins were diisopropyl ethor-acetic acid (50:1) mixture (IA) and hexane-acetic acid (9:1) mixture (HA). Di- and monoorganotins were detected on the chromatoplates with pyrocatechol violet ${ }^{10,11}$ or 8-hydroxy-5-quinolinesulfonic acid. ${ }^{12}$ Dithizone ${ }^{10}$ differentiates tri- and diorganotins and -leads, the tri-derivatives giving a yellow color and the di-derivatives a salmon color. Ultraviolet light was used to decompose the tetraorganometals and usually the triorganotins before detection. ${ }^{10,11}$ Quantitative analysis by gas-liquid chromatography (GLC) employed columns of $20 \%$ polyethylene glycol 1500 at $110^{\circ} \mathrm{C}$ or $20 \%$ polyethylene glycol 4000 at $150^{\circ} \mathrm{C}$, each on Chromosorb W $60-80$, the former for cyclohexanone and cyclohexanol and the latter for isomeric cyclohexanediols. l-Butene was detected using a glass capillary column modified for greater efficiency from a described system.13

Liver microsomes were used from rabbits, although preliminary studies involving also rats and mice showed no species difference in the products detected. The reaction mixtures contained $0.5 \mu \mathrm{mol}$ organotin or -lead substrate, microsome and soluble fractions equivalent to 400 and $40 \mathrm{mg}$, respectively, of fresh liver, and 0 or $2 \mu \mathrm{mol}$ reduced nicotinamide-adenine dinucleotide phosphate (NADPH) in $2 \mathrm{ml} 0.1$ $M$ phosphate buffer, $\mathrm{pH}$ 7.4. Following addition of the substrate in $50 \mu$ l ethanol as the last ingredient and incubation for $\mathrm{I} \mathrm{h}$ at $37^{\circ} \mathrm{C}$, organometallic products were recovered for TLC by extraction with ether-acetylacetone (9:1) mixture, before and after acidification with hydrochloric acid. The carbon fragments released were recovered for GLC by extraction of the incubation mixtures with ethyl acetate or the gas above the reaction mixtures in closed flasks was analyzed directly.

The extent of metabolism of triorganotins decreases with larger organic substituents, i.e. $\mathrm{Et}_{3} \mathrm{Sn}^{+}, \mathrm{Pr}_{3} \mathrm{Sn}^{+}$and $\mathrm{Bu}_{3} \mathrm{Sn}^{+}$ $>\mathrm{Pen}_{3} \mathrm{Sn}^{+}>\mathrm{Cy}_{3} \mathrm{Sn}^{+}>\mathrm{Hex}_{3} \mathrm{Sn}^{+} \gg \mathrm{Oct}_{3} \mathrm{Sn}^{+}$ $\gg \mathrm{Ph}_{3} \mathrm{Sn}^{+}$, the first five compounds being metabolized greater than $15 \%$ and the

Acta Chem. Scand. 25 (1971) No. 4 
Table 1. Number of organotin metabolites detected from various trialkyltins in the rabbit liver microsome-soluble-NADPH system.

\begin{tabular}{|c|c|c|c|c|}
\hline \multirow[t]{2}{*}{ Substrate } & \multicolumn{2}{|c|}{$\begin{array}{l}\text { Triorganotin } \\
\text { metabolites }\end{array}$} & \multirow{2}{*}{$\begin{array}{l}\text { Mono- and } \\
\text { diorganotin } \\
\text { metabolites }\end{array}$} & \multirow{2}{*}{$\begin{array}{c}\text { Total } \\
\text { number of } \\
\text { metabolites }\end{array}$} \\
\hline & Acid-labile & Acid-stable & & \\
\hline $\mathrm{Et}_{3} \mathrm{SN}^{+}$ & 1 & 0 & 2 & 3 \\
\hline $\mathrm{Pr}_{3} \mathrm{Sn}^{+}$ & 1 & 0 & 1 & 2 \\
\hline $\mathrm{Bu}_{3} \mathbf{S n}^{+}$ & 1 & 1 & 3 & 5 \\
\hline $\mathrm{Pen}_{3} \mathrm{Sn}^{+}$ & 3 & 2 & 5 & 10 \\
\hline $\mathrm{Hex}_{\mathbf{3}} \mathrm{Sn}^{+}$ & 1 & 2 & 2 & 5 \\
\hline $\mathrm{Cy}_{3} \mathrm{Sn}^{+}$ & 2 & 3 & 2 & 7 \\
\hline
\end{tabular}

phenyl derivative not at all. In these and all subsequent reactions discussed, both enzyme and NADPH are required to initiate metabolite formation. The metabolites of six of the trialkyltins were resolved by TLC using IA and then HA solvent systems for two-dimensional development (Table 1). In each case, there is one major acid-labile trialkyltin metabolite; this metabolite decomposes on acidifying the reaction mixtures with hydrochloric acid to $\mathrm{pH} 1$ before extraction or on evaporating the solvent, increasing the acetic acid concentration, from the chromatoplates after IA development, in each case to yield the corresponding dialkyltin. This metabolite is originally extracted at near neutral pH as a trialkyltin, giving the characteristic yellow color on quickly spraying dithizone reagent after development with the IA TLC solvent system and with an $R_{F}$ in this system between $\mathbf{R}_{3} \mathbf{S n}^{+}$ and $\mathbf{R}_{2} \mathrm{Sn}^{2+}$ suggesting that it has an additional polar substituent, such as a hydroxyl group. GLC analysis indicates that this metabolite of $\mathrm{Cy}_{3} \mathrm{Sn}^{+}$liberates cyclohexanone and cyclohexanol and of $\mathrm{Bu}_{3} \mathrm{Sn}^{+}$ liberates 1-butene.on decomposition to the dialkyltin. Thus, the major acid-labile trialkyltin metabolite, in each case, appears to be the 1-hydroxyalkyl dialkyltin. These metabolites were not obtained pure in adequate amounts for definitive characterization because they undergo partial decomposition under the conditions used so far for their isolation, and attempts to prepare them by reaction of $\mathbf{R}_{3} \mathrm{Sn}^{+}$with various chemical oxidants have not been completely successful. There are also other minor acid-labile trialkyltins derived from Pen ${ }_{3} \mathrm{Sn}^{+}$and $\mathrm{Cy}_{3} \mathrm{Sn}^{+}$and these are probably isomeric 1 -hydroxyalkyl dialkyltins each with one additional hydroxyl substituent on an alkyl group.

The acid-stable trialkyltin metabolites were detected only with the higher alkyl substituents, and in each case in smaller amount than the major acid-labile metabolite. They chromatograph below the $\mathrm{R}_{3} \mathrm{Sn}^{+}$precursor in the IA TLC solvent system and below both $\mathbf{R}_{3} \mathrm{Sn}^{+}$and $\mathbf{R}_{2} \mathrm{Sn}^{2+}$ in the HA solvent system. Three of these acid-stable metabolites from $\mathrm{Cy}_{3} \mathrm{Sn}^{+}$were isolated by preparative TLC and subjected to short wavelength ultraviolet light to examine their photodecomposition pruducts. Each one photodecomposes on TLC plates to $\mathrm{Cy}_{2} \mathrm{Sn}^{2+}$, among other products. In aqueous medium, each of these metabolites yields trans-1,2-cyclohexanediol but does not yield significant amounts of other cyclohexanediols or of cyclohexanone or cyclohexanol. On photodegradation of each of $\mathrm{Cy}_{4} \mathrm{Sn}, \mathrm{Cy}_{3} \mathrm{Sn}^{+}, \mathrm{Cy}_{2} \mathrm{Sn}^{2+}$, and $\mathrm{CySn}^{3+}$ in aqueous medium, the cyclohexanediols are very minor products, or absent, and cyclohexanone and cyclohexanol are prominent products. Thus, the acid-stable metabolites each contain a moiety degrading to trans1,2-cyclohexanediol but the overall balance of reactions involved is complex and so a definite structure cannot be proposed for the acid-stable metabolites on the basis of these photodecomposition experiments. However, these compounds are probably trialkyltins with one or two hydroxyl groups, on the alkyl substituents, but not at the 1-position. The major product detected from each trialkyltin is the corresponding dialkyltin, if the extraction or chromatography is carried out in strong acid conditions. There are also acidunstable dialkyltins detected as metabolites of $\mathrm{Bu}_{3} \mathrm{Sn}^{+}$and $\mathrm{Pen}_{3} \mathrm{Sn}^{+}$, probably con- 
taining a l-hydroxy substituent. $\mathrm{BuSn}^{3+}$ and $\mathrm{CySn}^{3+}$ were detected as metabolites of $\mathrm{Bu}_{3} \mathrm{Sn}^{+}$and $\mathrm{Cy}_{3} \mathrm{Sn}^{+}$, respectively.

The findings with other organotin and -lead compounds indicate a similar mech. anism of dealkylation: $\mathrm{Et}_{4} \mathrm{Sn}$ gives $\mathrm{Et}_{3} \mathrm{Sn}^{+}$and $\mathrm{Et}_{2} \mathrm{Sn}^{2+} ; \mathrm{Bu}_{2} \mathrm{Sn}^{2+}$ gives $\mathrm{BuSn}^{3+}$; $\mathrm{Cy}_{2} \mathrm{Sn}^{2+}$ gives $\mathrm{CySn}^{3+}$, cyclohexanone and cyclohexanol; $\mathrm{CySn}^{3+}$ does not give cyclohexanone or cyclohexanol; $\mathrm{Et}_{4} \mathrm{~Pb}$ gives $\mathrm{Et}_{3} \mathrm{~Pb}^{+} ; \mathrm{Bu}_{3} \mathrm{~Pb}^{+}$gives $\mathrm{Bu}_{2} \mathrm{~Pb}^{2+}$ and 1-butene; $\mathrm{Ph}_{3} \mathrm{~Pb}^{+}$is not metabolized. Apparently, a hydrogen at the 1-position is necessary for rapid microsomal degradation of organotin and -lead compounds.

The findings from these microsomal studies on alkyltins and -leads are in complete agreement with the previous studies on microsomal preparations and living mammals but the present study greatly extends the available information and allows some generalizations on the mechanisms for metabolism in mammals. There is sequential dealkylation of tetra-, tri-, and dialkyltin compounds to the monoalkyltin derivatives and of tetra- and trialkyllead compounds, at least to the dialkyllead derivatives. The carbon moiety is released on microsomal dealkylation of $\mathrm{Bu}_{3} \mathrm{Sn}^{+}$and $\mathrm{Bu}_{3} \mathrm{~Pb}^{+}$as 1-butene and of $\mathrm{Cy}_{3} \mathrm{Sn}^{+}$and $\mathrm{Cy}_{2} \mathrm{Sn}^{2+}$ as a mixture of cyclobexanone and cyclohexanol. Apparently, the dealkylation of organotins and -leads involves hydroxylation at the 1-position and liberation of the 1-alkene from $n$-alkyl substituents and the ketones and alcohols from sec-alkyl substituents. The enzymatic mechanism for cleavage of alkyltin compounds can be summarized as follows $\left[\mathbf{R}_{1}=\right.$ $\mathrm{CH}_{3}\left(\mathrm{CH}_{2}\right)_{n}-$ and $\mathrm{R}_{2}=\mathbf{H}$ for the $n$-alkyl series; $\mathbf{R}_{1}$ and $\mathbf{R}_{2}$ are part of the alicyclic system for cyclohexyl derivatives]:

$$
\begin{aligned}
& \left(\mathbf{R}_{1} \mathbf{R}_{2} \mathrm{CH}\right), \mathrm{Sn} \rightarrow\left[\left(\mathbf{R}_{1} \mathbf{R}_{2} \mathrm{CH}\right)_{3} \mathrm{SnC}(\mathrm{OH}) \mathrm{R}_{1} \mathbf{R}_{2}\right] \\
& \rightarrow\left(\mathbf{R}_{1} \mathbf{R}_{2} \mathrm{CH}\right)_{3} \mathrm{Sn}^{+} \rightarrow \\
& \left(\mathbf{R}_{1} \mathbf{R}_{2} \mathrm{CH}\right)_{2} \mathrm{Sn}^{+} \mathrm{C}(\mathrm{OH}) \mathbf{R}_{1} \mathbf{R}_{2} \rightarrow \\
& \left(\mathbf{R}_{1} \mathbf{R}_{2} \mathrm{CH}\right)_{2} \mathrm{Sn}^{2+} \rightarrow \\
& \mathbf{R}_{1} \mathbf{R}_{2} \mathrm{CHSn}{ }^{+} \mathrm{C}(\mathrm{OH}) \mathrm{R}_{1} \mathbf{R}_{2} \rightarrow \mathrm{R}_{1} \mathbf{R}_{2} \mathrm{CHSn}^{3+}
\end{aligned}
$$

In addition to this metabolic sequence based on hydroxylation at the 1-position, there is probably also hydroxylation at other positions in the alkyl substituents at least with $\mathrm{Et}_{3} \mathrm{Sn}^{+}, \mathrm{Bu}_{3} \mathrm{Sn}^{+}, \mathrm{Pen}_{3} \mathrm{Sn}^{+}$,
Hex ${ }_{3} \mathrm{Sn}^{+}$, and $\mathrm{Cy}_{3} \mathrm{Sn}^{+}$. The biological activity and toxicological significance of the hydroxyalkyltin and -lead metabolites remain to be evaluated.

Acknowledgements. This work was supported in part by the Swedish Board for Technical Development, the United States National Institutes of Health (Grant ESGM 00049) and The Rockefeller and Guggenheim Foundations. For advice or assistance the authors thank Professors Klas-Bertil Augustinsson, Herrick Baltcheffsky and Lars Ernster, Dr. Erik Arrhenius, Mr. Anders Laveskog and Mrss. Eva Bergstedt of the University of Stockholm, Miss Judith Engel of the University of California, Berkeley, Drs. Grant Smith and Henry Gray of The Dow Chemical Co., Midland, Michigan, and Dr. G. M. van der Want of the Institute of Organic Chemistry TNO, Utrecht, the Netherlands.

1. Cremer, J. E. Biochem. J. 68 (1958) 685.

2. Cremer, J. E. Brit. J. Industr. Med. 16 (1959) 191.

3. Stevens, C. D., Feldhake, C. J. and Kehoe, R. A. J. Pharmacol. Exp. Therap. 128 (1960) 90.

4. Bolanowska, W. Brit. J. Industr. Med. 25 (1968) 203.

5. Rose, M. S. and Aldridge, W. N. Biochem. J. 106 (1968) 821.

6. Bridges, J. W., Davies, D. S. and Williams, R. T. Biochem. J. 105 (1967) 1261.

7. Smith, G. N. The Dow Chemical Co., Midland, Michigan. Private communication.

8. Herok, J. and Götte, H. Int. J. Appl. Radiat. Isotop. 14 (1963) 461.

9. Heath, D. F. Radioisotopes in the Detection of Pesticide Residues, IAEA, Vienna 1966, p. 18.

10. Stahl, E., Ed., Thin-Layer Chromatography, Springer, Berlin 1969, pp. 664665.

11. Williams, D. J. and Price, J. W. Analyst 85 (1960) 579.

12. Pal, B. K. and Ryan, D. E. Anal. Chim. Acta 48 (1969) 227.

13. Bartle, K. D., Bergstedt, L., Novotny, M. and Widmark, G. J. Chromatog. 45 (1969) 256.

Received April 30, 1971. 